\title{
PELATIHAN EDUTECH FOR CHILDREN UNTUK MENINGKATKAN KEMAMPUAN TEKNIS DAN MELATIH POLA PIKIR INOVATIF SISWA
}

\author{
Deny Nusyirwan $^{1)^{*}}$, Eko Prayetno ${ }^{2)}$, Henry Ali Singer $^{3)}$, Sapta Nugraha ${ }^{4)}$, Anton Hekso \\ Yunianto $^{5)}$, Tonny Suhendra ${ }^{6)}$, Afdal Hadi ${ }^{7)}$, Allysia Shafira ${ }^{8)}$, Desi Oktavia ${ }^{9)}$, Lilis \\ Agustina Sinaga ${ }^{10}$ \\ ${ }^{1)}$ Program Studi Teknik Elektro, Universitas Maritim Raja Ali Haji (UMRAH) \\ Jl. Politeknik Senggarang, Tanjungpinang 29100, email: denynusyirwan@umrah.ac.id \\ ${ }^{2)}$ Program Studi Teknik Elektro, Universitas Maritim Raja Ali Haji (UMRAH) \\ Jl. Politeknik Senggarang, Tanjungpinang 29100 \\ ${ }^{3}$ Corporate Social Responsibility, Banyan Tree Hotels and Resorts Bintan \\ Jalan Teluk Berembang Laguna Bintan Lagoi 29155 \\ ${ }^{4-10)}$ Program Studi Teknik Elektro, Universitas Maritim Raja Ali Haji (UMRAH) \\ Jl. Politeknik Senggarang, Tanjungpinang 29100
}

\begin{abstract}
ABSTRAK
Pendidikan pada usia dini menjadi sebuah fenomena menarik pada saat ini di Indonesia,dapat dilihat dari menjamurnya taman pendidikan untuk anak yang belum bisa masuk sekolah. Provinsi Kepulauan Riau (Kepri) yang lokasinya berbatasan langsung dengan Gerbang Internasional Singapura dan Malaysia secara tidak langsung diminta untuk mampu berkompetisi secara secara softskill dan hardskill. Untuk menghadapi kesempatan tersebut dan menciptakan generasi yang mampu bersaing secara global, jurusan Teknik Elektro Universitas Maritim Raja Ali Haji (UMRAH) melalui tridharma perguruan tinggi, bekerjasama dengan bagian Corporate Social Responsibility (CSR) Banyan Tree Hotel and Resorts Bintan, menghasilkan sebuah program bernama Edutech for Children (EfC). EfC adalah program untuk meningkatkan kemampuan siswa berpikir secara kritis dan analisis pada usia dini melalui pengenalan proses perancangan rekayasa dan pelatihan pola pikir insinyur untuk siswa di sekolah. Dimulai dari proses etnografi, brainstorming, menentukan permasalahan dan solusi utama dan merancang menggunakan perangkat lunak 3 dimensi Autodesk inventor. Sebuah inovasi yang merupakan luaran dari proses desain rekayasa adalah merupakan hasil dari proses rancangan yang berbasiskan kepada pengguna dengan menggunakan pendekatan etnografi, oleh sebab itu melalui pelatihan yang diberikan siswa akan diajak untuk mampu memahami bahwa sebuah inovasi tersebut membutuhkan integrasi kemampuan berpikir secara luas terhadap permasalahan yang ada di masyarakat. Dengan kegiatan ini didapatkan hasil memuaskan yang dibuktikan dengan meningkatnya kemampuan teknis dan munculnya pola pikir inovatif sehingga siswa mampu untuk menemukan dan merancang teknologi yang sesuai untuk kebutuhan setempat.
\end{abstract}

Kata kunci: Berpikir, Kompetisi, Kemampuan, Siswa, Teknologi

\section{ABSTRACT}

Education at an early age is an interesting phenomenon at this time in Indonesia, can be seen from the mushrooming of educational parks for children who have not been able to go to school. Riau Islands Province (Riau Islands) whose location is directly adjacent to the International Gates of Singapore and Malaysia is indirectly requested to be able to compete in soft skills and hard skills. To face this opportunity and create a generation that is able to compete globally, the Department of Electrical Engineering, Raja Ali Haji Maritime University (UMRAH) through the three-tridharma of higher education, in collaboration with the Corporate Social Responsibility (CSR) section of the Banyan Tree Hotel and Resorts Bintan, produced a program called Edutech for Children (EfC). EfC is a program to improve students 'ability to think critically and analyze at an early age through the introduction of the engineering design process and training of engineers' mindsets for students in schools. 
Starting from the ethnographic process, brainstorming, determining the main problems and solutions and designing using Autodesk Inventor's 3-dimensional software. An innovation which is an outcome of the engineering design process is the result of a design process based on the user using an ethnographic approach, therefore through training provided students will be invited to be able to understand that an innovation requires the integration of broad thinking skills towards problems exist in the community. With this activity, satisfying results are evidenced by increasing technical ability and the emergence of innovative mindsets so that students are able to find and design technologies that are suitable for local needs.

Keywords: Thinking, Competition, Performance, Student, Technology

\section{PENDAHULUAN}

Saat ini peneliti mengidentifikasi bahwa pengenalan pendidikan untuk bidang rekayasa di Sekolah Dasar adalah periode penting untuk meningkatkan kesadaran dan peminatan siswa tentang rekayasa sebagai jalur karir. Oleh karena itu, diperlukan sebuah pendekatan yang diharapkan dapat memperkenalkan proses rekayasa pada periode tersebut, yaitu dengan mengintegrasikan proses perancangan rekayasa untuk dapat menjadi salah satu komponen pada kurikulum di sekolah menengah [1]. Selain itu juga perlu melatih pola pikir layaknya rekayasawan dengan memberikan permasalahan-permasalahan yang menantang, sehingga istilah engineering is not for me tidak akan muncul [2]. Peranan penting bagi ilmuwan pada abad ke-21 adalah berperan serta dalam mendidik masyarakat tentang metode dan hasil proses ilmiah [3].

Dari hasil observasi yang dilakukan di sekolah dasar dan menengah, ditemukan minat siswa terhadap teknologi cukup tinggi. Hal ini dibuktikan dengan jumlah siswa yang hadir ketika pengenalan teknologi ke sekolah-sekolah. Untuk mendukung minat siswa tersebut, maka jurusan Teknik Elektro Universitas Maritim Raja Ali Haji (UMRAH) melalui tridharma perguruan tinggi, bekerjasama dengan bagian Corporate Social Responsibility (CSR) Banyan Tree Hotel and Resorts Bintan melihat perlunya pendampingan didalam memberikan penguatan kemampuan penguasaan teknologi dan menumbuhkan pola pikir seorang rekayasawan pada usia dini dengan menghasilkan sebuah program bernama Edutech for Children (EfC).

Edutech for Children (EfC) adalah merupakan kegiatan pengenalan proses perancangan rekayasa pada siswa dengan memperkenalkan teknologi dan rekayasa menggunakan pendekatan yang sederhana dan bersahabat, dengan tujuan untuk dapat menumbuhkan minat siswa terhadap rekayasa, dengan cara melatih para siswa untuk mampu bekerja sama, berpikir kreatif dan memahami proses untuk menghasilkan inovasi teknologi yang merupakan solusi yang tepat bagi permasalahan di lingkungannya. Pada Gambar 1, menampilkan acara pembukaan pelatihan Edutech for Children di Kabupaten Bintan. 


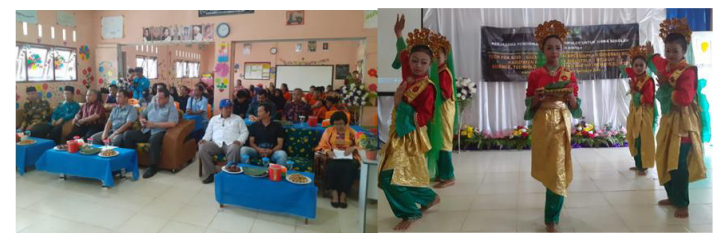

Gambar 1. Acara Pembukaan Pelatihan Edutech for Children di Kabupaten Bintan

\section{METODE PELAKSANAAN}

Desain dan kreativitas menjadi keterampilan yang sangat dicari dalam industri terkemuka di seluruh dunia, perusahaan besar mengembangkan "Chief Design Officer" untuk terlibat dengan diskusi strategis dan sebagai pendorong ekonomi perusahaan, oleh sebab itu diperlukan menanamkan "kreativitas" ke dalam pendidikan tingkat sekolah menengah dan universitas untuk mendorong inovasi dan pengembangan tingkat selanjutnya [4].Selama siklus proses perancangan rekayasa, rekayasawan diharapkan untuk sepenuhnya memahami kebutuhan pelanggan walaupun menghadapi tantangan berupa geografis, jadwal proyek yang sempit, atau anggaran yang pendek [5].

EfC menerapkan pola pendampingan selama pelatihan berlangsung, dengan meminta bantuan dari para mahasiswa yang disebut sebagai fasilisator untuk berinterakasi langsung dengan siswa dan siswi SD selama proses pelatihan berlangsung. Dalam program EfC ini, pemberian motivasi dan membangkitkan rasa ingin tahu mengenai teknologi dan pendekatan secara emosional kepada para siswa sangat diperlukan untuk menimbulkan minat para siswa mengenal proses rekayasa. Pada Gambar 2 menampilkan tahapan pada Proses Desain Rekayasa Stanford Design School dengan pendekatan Design Thinking

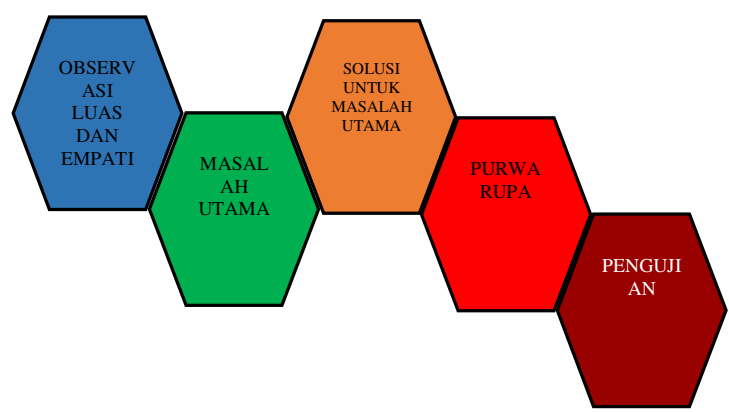

Gambar 2. Tahapan pada Proses Desain Rekayasa Stanford Design School dengan pendekatan Design Thinking

(https://www.enterpriseirregulars.com/)

Materi-materi dasar akan diberikan pada pertemuan awal dan selanjutnya mengarahkan siswa melakukan observasi untuk dapat menemukan permasalahanpermasalahan di lingkungan sekolah. Adapun pada tahapan selanjutnya para siswa akan menentukan satu permasalahan utama, dan dengan pola curahan gagasan para siswa akan diminta kembali berdiskusi untuk memberikan solusi-solusi, pola pelatihan ini disebut proses perancangan rekayasa yang berbasis kepada pengguna dengan pendekatan design thinking. Metodelogi Design Thinking digunakan oleh desainer untuk memecahkan masalah yang kompleks, mampu menghilangkan ketakutan akan kegagalan dan mendorong partisipasi maksimum dari setiap anggota. Inovasi yang dhasilkan oleh Design Thinking tidak selalu tentang membuat perangkat berteknologi tinggi berikutnya, namun menitik beratkan untuk menyusun solusi yang menyentuh 
pengguna akhir dengan cara yang bermakna.

Siswa akan diminta untuk menggambarkan sebuah solusi utama terlebih dahulu diatas kertas dan selanjutnya akan didesain menggunakan perangkat lunak autodesk inventor, proses menggambar menggunakan komputer untuk dapat menghasilkan rancangan dinamakan purwarupa virtual, yang merupakan satu bagian dari proses perancangan rekayasa.

Adapun tujuan ahir dari pengabdian adalah memberikan penguatan kepribadian dan akademik siswa dengan menciptakan suasana belajar yang kreatif, kritis dalam menganalisa dan mampu bekerjasama dengan rekan satu kelompok yang merupakan bagian terintegrasi untuk pola pembelajaran di era revolusi industri 4.0.

SD Negeri 004 Teluk Sebong berada di wilayah Desa Ekang Anculai Kecamatan Teluk Sebong Kabupaten Bintan dengan akses jalan masuk yang mudah. Lokasi sekolah berdekatan dengan pemukiman masyarakat, sila lihat Gambar 3.

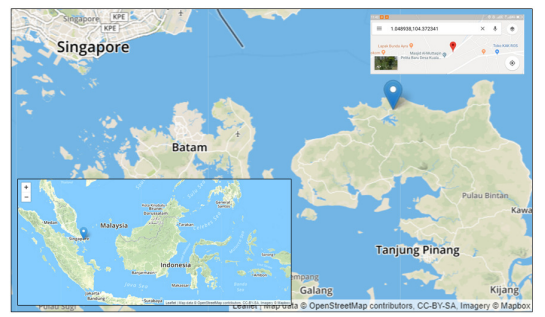

Gambar 3. Lokasi SDN 004 Teluk Sebong, Kabupaten Bintan, Provinsi Kepulauan Riau (https://referensi.data.kemdikbud.go.id/t abs.php?npsn=11001923)

Berdiri tahun 1976 dan pada tahun pelajaran 2019 - 2020 memiliki kelas I - VI dengan rombongan belajar berjumlah 6 kelas. Kondisi wilayah sekitar merupakan daerah pertanian dan sebagian besar orang tua siswa bermata pencaharian sebagai petani dan buruh. Siswa-siswi SD Negeri 004 Teluk Sebong, $80 \%$ penduduk aslinya suku Jawa, $20 \%$ masyarakat Tionghoa. Karena orang tuanya bekerja sebagai petani, hubungan sosial lingkungan terjalin sangat harmonis. Siswa siswi SD Negeri 004 Teluk Sebong dalam perkembangan akademis (nilai akademis/koqnitif), $\quad 70 \%$ dapat mengikuti dengan baik, sesuai KKM yang ditetapkan. Pada Gambar 4, menampilkan lingkungan sekolah dan siswadi SDN 004 Teluk Sebong.

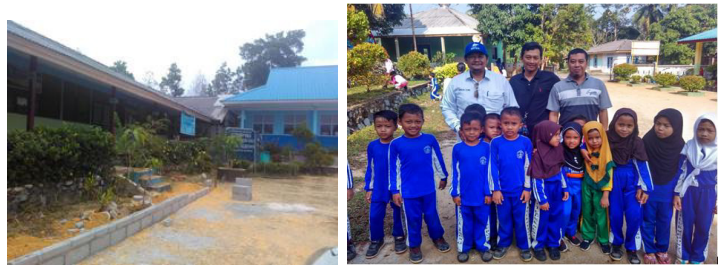

Gambar 4. Lingkungan Sekolah dan

SiswaSDN 004 Teluk Sebong Kabupaten Bintan

Pendidikan diselenggarakan secara terpadu berdasarkan konsep one for all, yaitu memadukan pendidikan umum, pendidikan agama dan pendidikan ketrampilan dengan proses pembelajaran menuju ke sistem full day school, sehingga waktu pendidikan di sekolah lebih lama, terencana dan terarah.Pelatihan dilaksanakan 1(satu) kali dalam seminggu yang di agendakan pada setiap hari sabtu. Dalam pertemuan pertama diberikan pemahaman kepada siswa mengenai proses desain rekayasa beserta tahapannya. Pada minggu selanjutnya fasilisator pelatihan akan 
mendampingi siswa dan siswa dalam setiap ahir kegiatan nantinya, sila lihat Tabel 1.

tahapan hingga menghasilkan luaran pada

Tabel 1. Agenda Pelatihan Edutech for Children Tahun 2019.

\begin{tabular}{|c|c|c|}
\hline & Materi & Disampaikan Oleh \\
\hline Pertemuan 1. & $\begin{array}{l}\text { 1. Brainstroming permasalahan } \\
\text { 2. Penentuan masalah utama } \\
\text { 3. Brainstorming solusi } \\
\text { 4. Sketching ( menggunakan kertas dan } \\
\text { pena/pensil) } \\
\text { 5. Menggambar menggunakan } \\
\text { perangkat lunak autodesk inventor } \\
\text { 6. Pengujian }\end{array}$ & fasilisator pelatihan \\
\hline $\begin{array}{l}\text { Pertemuan 2- } \\
6\end{array}$ & $\begin{array}{l}\text { Menggunakan komputer untuk } \\
\text { menghasilkan purwarupa digital } \\
\text { menggunakan Autodesk Inventor }\end{array}$ & fasilisator pelatihan dan siswa/i \\
\hline $\begin{array}{l}\text { Pertemuan } \\
\text { ahir }\end{array}$ & Presentasi hasil pelatihan & Siswa/i \\
\hline
\end{tabular}

Adapun nama mahasiswa yang menjadi fasilisator dalam pelatihan dan siswa yang terlibat dalam pelatihan Edutech for Children dapat dilihat pada Tabel 2.

Tabel 2. Data Peserta dan Fasilisator Penamping Pelatihan Edutech for Children Tahun 2019

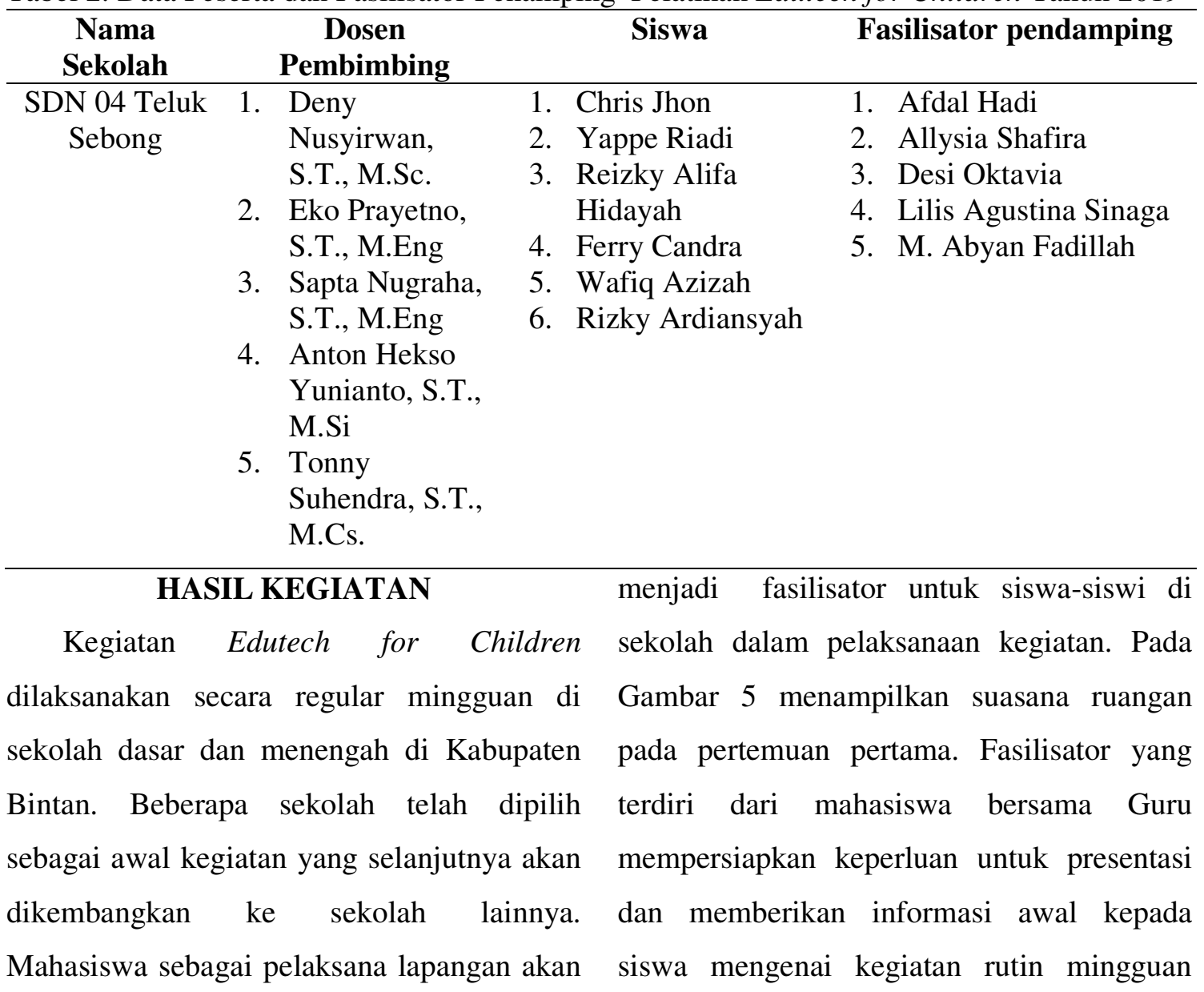


mengenai proses desain rekayasa

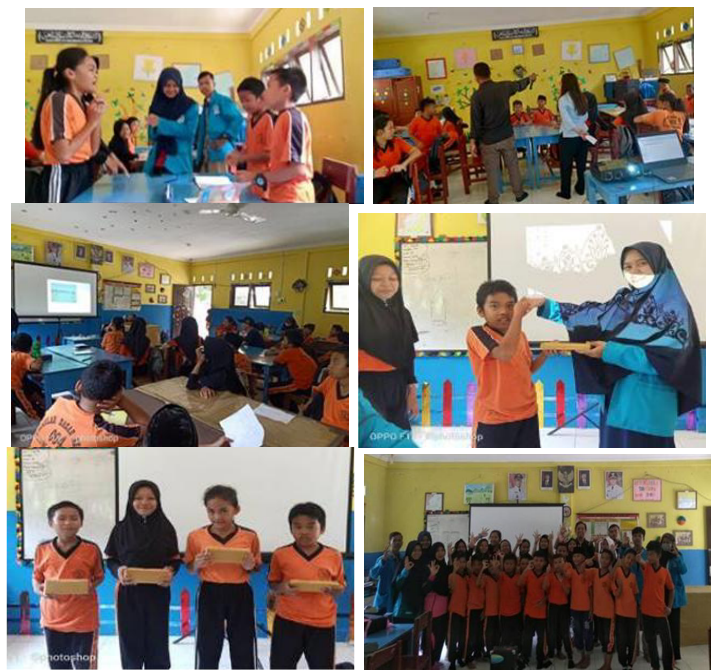

Gambar 5. Suasana pembelajaran pada pertemuan pertama

Setelah selesai pada tahapan awal, pengantar mengenai proses desain rekayasa kepada peserta, maka pelatihan dilanjutkan dengan tahapan berikut.

\section{Etnografi}

Saat ini teknologi yang dihasilkan adalah merupakan solusi terhadap permasalahan yang ada di masyarakat, oleh sebab itu diperlukan data yang lengkap terhadap permasalahan yang ada pada masyarakat di satu daerah.Untuk itu diperlukan pola pendekatan secara sioal yang dinamakan etnografi.

Etnografi adalah merupakan bagian awal dari Proses Desain Rekayasa, dimana dalam observasi tahapan ini diperlukan pendekatan secara sosial dan memerlukan jangka waktu tertentu didalam pelaksanaannya di lapangan.Pendekatan secara sosial berupa hidup bersama di lingkungan masyarakat dan melakukan aktifitas seperti biasa di masyarakat setempat. Selanjutnya melakukan pendataan mengenai pola hidup masyarakat tersebut yang akan dijadikan sebagai masukan untuk inovasi berbasiskan teknologi Dengan metode observasi yang berbasiskan etnografi, peneliti akan dapat mengumpulkan data secara lengkap dengan melihat dan mengalami secara langsung peristiwa dan kondisi apa yang terjadi, hal ini sangat dianjurkan karena kesulitan yang dialami oleh pengguna untuk mengekspresikan kebutuhan dan keinginan mereka [6]. Pada Gambar 6 menunjukkan mahasiswa sebagai fasilisator pelatihan berintegrasi langsung dengan siswa, melakukan kegiatan yang sama dan memberikan pandangan-pandangan yang diperlukan untuk melatih siswa dan siswi dalam melakukan observasi terhadap lingkungan sekitarnya.

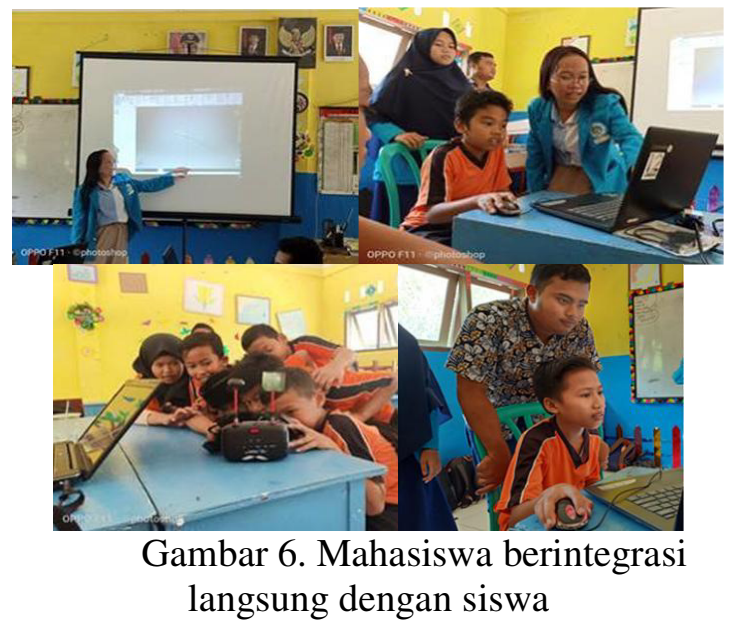

\section{Curahan gagasan permasalahan}

Siswa dan siswi melakukan brain storming terhadap permasalahan yang ada di sekitarnya. Masing-masing siswa menyampaikan secara cepat dengan cara menulis atau menggambar. 


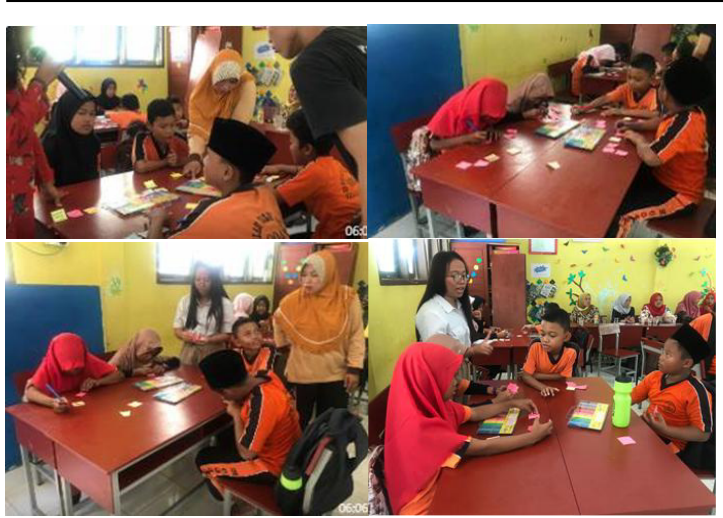

Gambar 7. Siswa dan siswi melakukan curahan gagasan menggunakan post it

Pada Gambar 7 menunjukkan suasana yang santai dan fun akan menghasilkan dorongan terhadap siswa dan siswi untuk mampu menemukan permasalahanpermasalahan di sekitarnya dengan lebih baik. Fasilisator akan membantu menyediakan peralatan yang diperlukan agar Brainstorming secara cepat. Pola penyampaian gagasan melalui brain storming sangat diperlukan untuk memotivasi siswa mampu berpikir inovatif dan kratif. Curahan gagasan yang bersifat luas (divergence) adalah merupakan pondasi untuk inovasi yang berbasiskan teknologi, hal ini sering dipahami dengan $\mathrm{T}$ concept di dalam bidang rekayasa, dimaksudkan bahwa inovasi yang dihasilkan memiliki pengaruh yang luas dan mendalam. Adapun aturan-aturan di dalam brainstorming adalah menghindari penilaian secara langsung dan membantah ide yang sedang disampaikan., mendorong adanya ideide yang luar biasa/aneh, berpikir seperti anak kecil dimana tidak takut akan kesalahan., mengedepankan kuantitas daripada kualitas., mempertahankan semua pembicaraan dan diskusi serta ide yang disampaikan tetap pada topic dan tidak ada yang berbicara secara bersamaan [7].

\section{Menentukan permasalahan utama}

Setelah mengumpulkan permasalahanpermasalahan yang ada di sekolah, selanjutnya akan dilakukan pengelompokan untuk menentukan permasalahan utama nantinya.

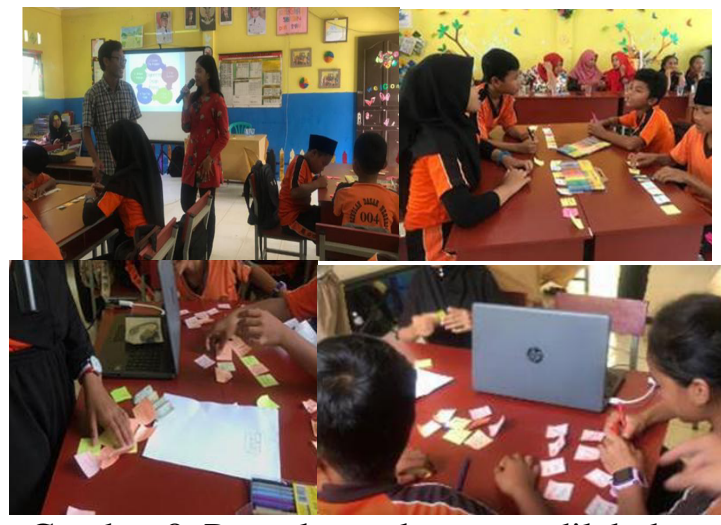

Gambar 8. Pengelompokan yang dilakukan secara langsung sesama anggota keompok untuk menentukan permasalahan utama

Permasalahan utama adalah permasalahan yang akan di angkat untuk langkah penentuan solusi, dalam tahapan ini akan di pilih satu masalah saja. Proses diskusi bersama sesama anggota kelompok, selanjutnya memberikan penjelasan terhadap masalah yang akan dijadikan masalah utama. Dalam proses ini perlu dipertimbangkan adalah keputusan yang akan diambil adalah merupakan keputusan bersama anggota lainnya.Pada Gambar 8 menunjukkan proses pengelompokan yang dilakukan didepan kelas secara langsung sehingga dapat dilakukan diskusi internal kelompok, dimana setiap anggota diminta untuk aktif 
menyampaikan pendapat.Pada tahapan ini dilakukan proses convergence terhadap permasalahan.

\section{Penentuan solusi}

Tahapan selanjutnya adalah proses divergence terhadap permasalahan utama. Beberapa konsep solusi akan diutarakan melalui proses brainstorming bersama anggota lainnya dengan mempergunakan kertas untuk menulis atau menggambatkan solusi. Pada ahir tahapan ini adalah pemilihan satu konsep solusi yang akan dikerjakan pada tahapan selanjutnya. Solusi utam yang diambil adalah merupakan solusi yang akan berdampak luas untuk masyarakat nantinya.

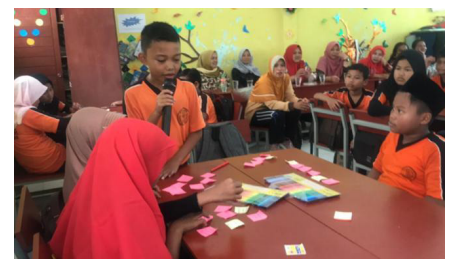

Gambar 9. Proses curahan gagasan untuk mendorong siswa dalam meberikan solusi secara bebas

Pada Gambar 9 menunjukkan proses curahan gagasan kembali dilakukan untuk memberikan kesempatan kepada siswa-siswi untuk berpikir secara bebas menyampaikan pendapat dengan menggunakan kertas. Setelah tahapan divergence solution selesai, maka siswa dan siswi akan menentukan satu solusi yang akan dijadikan sebagai landasan ke tahapan selanjutnya.

\section{Sketching}

Sketching diperlukan oleh siswa untuk mampu mendorong ide-ide yang bisa disampaikan lewat brainstorming.Sedangkan untuk pengguna teknologi, akan dapat melihat konsep awal dari solusi yang diberikan.diskusi secara internal kelompok dapat dilakukan untuk memberikan masukan terhadap rancangan awal. Sangat didorong untuk menggunakan kertas dan pensil karena akan lebih mudah melakukan perubahan jika ada ide lainnya yang akan dikembangkan.

Teknik mensketsa secara manual sesuai untuk menyampaikan ide pada tahapan awal dari penelitian, dimana teknik ini sudah diterapkan oleh perancang (designer) di dunia industri.

Metode perancangan yang menggunakan kertas dan pensil ataupun bahan-bahan pendukung lain sangat dianjurkan untuk menurunkan biaya didalam penelitian. Selain itu tujuan sketsa dalam domain teknik adalah menyediakan komunikasi dan pengambilan keputusan yang lebih cepat pada tahap awal desain, dengan memberikan gabungan visual dan faktual deskripsi untuk peningkatan evaluasi dan pemilihan konsep [8]. Sketsa desain tidak menggambar sesuatu yang sudah ada, sebagai contoh gambar tokoh, gambar benda hidup dan sejenisnya. Sebaliknya sang desainer terlibat dalam proses berusaha memberikan definisi eksternal kepada sesuatu yang dibayangkan [9] Pada Gambar 10 dapat dilihat hasil rancangan yang dilakukan oleh siswa. 


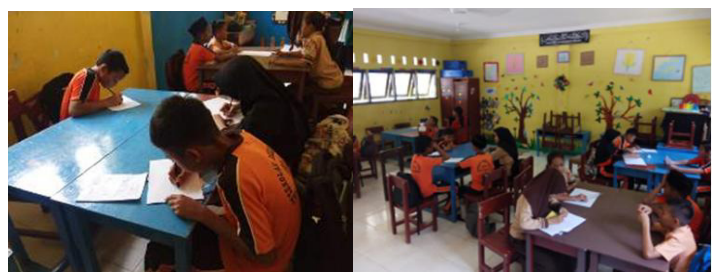

Gambar 10. Mensketsa di atas kertas

\section{Purwarupa Virtual}

Dalam tahapan ini, telah dimulai menggambar menggunakan komputer untuk mendapatkan tampilan detil awal secara virtual 3 dimensi.Beberapa perubahan dapat dikerjakan secara langsung. Pada Gambar 11 menunjukkan siswa melakukan proses transformasi dari sketsa yang digambar di atas kertas ke komputer.

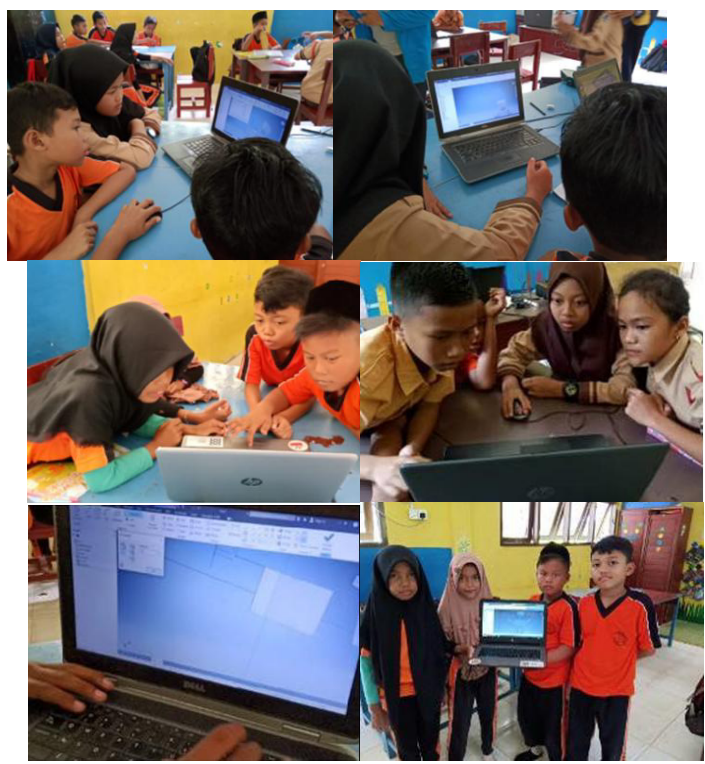

Desainer menggunakan model virtual untuk menggantikan purwarupa nyata dan menganalisisnya menggunakan berbagai jenis simulasi yang bertujuan untuk menciptakan kembali kondisi kehidupan nyata di mana produk perlu beroperasi. Proses ini dibantu oleh program komputer modern, yang dibuat untuk membantu para rekayasawan modern dalam pekerjaan mereka. Model virtual dibuat akan mencerminkan gambar nyata, atau sedekat mungkin dengan nyata [10].

Keuntungan utama dari purwarupa virtual adalah pembuatan purwarupa dari konsep inovasi untuk pengujian awal tidak diperlukan karena setiap penyesuaian akan dilakukan secara langsung dalam realitas virtual dengan mempergunakan simulasi. Purwarupa dapat di explorasi secara virtual dan interaktif, selanjutnya dapat dipelajari dan disimulasikan sebelum implementasi di dunia nyata [11]. Setelah selesai Edutech for Children, mahasiswa sebagai fasilisator memberikan kesempatan kepada orang tua siswa untuk memberikan tanggapan terkait pelatihan yang sudah diberikan selama beberapa minggu, sila lihat pada Gambar 12 .

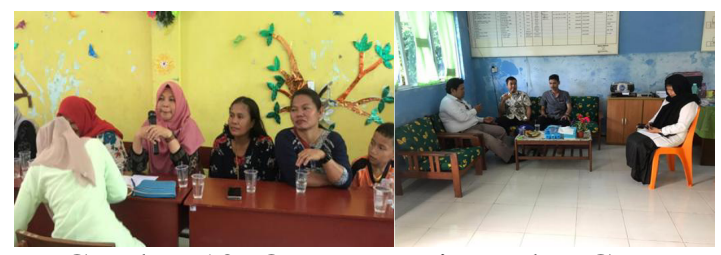

Gambar 12. Orang tua siswa dan Guru memberikan masukan mengenai pelatihan yang sudah diberikan selama 7 minggu pertemuan

Kegiatan Edutech for Children, dimulai dengan pelatihan rutin mingguan di sekolah dasar dan menengah telah mendorong siswa dan sekolah untuk meningkatkan pengetahuan dengan penguasaan teknologi dan meningkatakan prestasi siswa di sekolah atau daearah. Kemampuan berfikir secara luas yang diperkenalkan didalam proses 195 
siswa akan pentingnya teknologi. Demikian keinginan siswa untuk belajar menggambar juga sekolah yang termotivasi untuk menggunakan autodesk inventor juga telah mendorong siswa tidak hanya menjadi menunjukkan keberhasilan dari program pengguna teknologi. Meningkatnya TFK.

Tabel 3. Hasil Pelatihan Edutech for Children di SDN 04 Teluk Sebong

\begin{tabular}{|c|c|c|c|c|}
\hline \multicolumn{5}{|c|}{ Pembelajaran \& Inovasi } \\
\hline \multicolumn{5}{|c|}{ Kreativitas dan Inovasi } \\
\hline \multicolumn{5}{|c|}{ Bekerja Kreatif dengan Orang Lain } \\
\hline & $\begin{array}{l}\text { Sangat Baik } \\
\text { Terlibat dalam } \\
\text { beberapa teknik } \\
\text { pembuatan ide } \\
\text { dan } \\
\text { berpartisipasi } \\
\text { penuh dengan } \\
\text { menawarkan } \\
\text { pertanyaan yang } \\
\text { mendalam dan } \\
\text { mendengarkan } \\
\text { dengan baik } \\
\text { kepada orang } \\
\text { lain di dalam } \\
\text { grup. }\end{array}$ & $\begin{array}{c}3 \\
\text { Baik } \\
\text { Terlibat dalam } \\
\text { teknik } \\
\text { pembuatan ide } \\
\text { dan } \\
\text { berpartisipasi } \\
\text { dengan } \\
\text { menawarkan } \\
\text { ide }\end{array}$ & $\begin{array}{c}2 \\
\text { Cukup } \\
\text { Tidak } \\
\text { menawarkan ide } \\
\text { selama } \\
\text { pembuatan ide, } \\
\text { tetapi } \\
\text { mendengarkan } \\
\text { secara aktif } \\
\text { kepada anggota } \\
\text { grup lainnya }\end{array}$ & $\begin{array}{c}1 \\
\text { Kurang } \\
\text { Tidak berpartisipasi } \\
\text { aktif dalam } \\
\text { pembuatan ide }\end{array}$ \\
\hline $\begin{array}{l}\text { Menggunakan } \\
\text { berbagai teknik } \\
\text { pembuatan } \\
\text { ide(brainstorming } \\
\text { dll ...) }\end{array}$ & & & & \\
\hline \multicolumn{5}{|c|}{ Komunikasi dan Kolaborasi } \\
\hline \multicolumn{5}{|c|}{ Berkomunikasi dengan Jelas } \\
\hline & $\begin{array}{c}4 \\
\text { Sangat Baik } \\
\text { Tercermin } \\
\text { dengan serius } \\
\text { dan } \\
\text { mengidentifikasi } \\
\text { cara-cara } \\
\text { konstruktif } \\
\text { untuk } \\
\text { menerapkan } \\
\text { pengetahuan, } \\
\text { nilai, sikap, dan } \\
\text { niatpesan }\end{array}$ & $\begin{array}{c}3 \\
\text { Baik } \\
\text { Efektif } \\
\text { tercermin pada } \\
\text { makna, nilai, } \\
\text { sikap, dan niat } \\
\text { pesan }\end{array}$ & $\begin{array}{c}2 \\
\text { Cukup } \\
\text { Berusaha untuk } \\
\text { mendengarkan } \\
\text { pesan dan } \\
\text { merefleksikan } \\
\text { makna pesan, } \\
\text { tetapi } \\
\text { kehilangan } \\
\text { informasi kunci, } \\
\text { nilai, sikap atau } \\
\text { niat dan } \\
\text { merindukan } \\
\text { pentingnya } \\
\text { pesan }\end{array}$ & $\begin{array}{c}1 \\
\text { Kurang } \\
\text { Mendengarkan } \\
\text { pesan tetapi tidak } \\
\text { menunjukkan } \\
\text { pemahaman pesan } \\
\text { dengan tidak } \\
\text { merefleksikan } \\
\text { maknanya }\end{array}$ \\
\hline $\begin{array}{l}\text { Mendengarkan } \\
\text { secara efektif } \\
\text { untuk } \\
\text { menguraikan } \\
\text { makna, termasuk } \\
\text { pengetahuan, }\end{array}$ & & & & \\
\hline
\end{tabular}




\begin{tabular}{|c|c|c|c|c|}
\hline $\begin{array}{l}\text { nilai, sikap, dan } \\
\text { niat }\end{array}$ & & & & \\
\hline \multicolumn{5}{|c|}{ Berkolaborasi } \\
\hline & $\begin{array}{c}4 \\
\text { Sangat Baik } \\
\text { Secara konsisten } \\
\text { mendengarkan } \\
\text { orang } \\
\text { lain.Semua } \\
\text { pernyataan, } \\
\text { tanggapan, dan } \\
\text { bahasa tubuh, } \\
\text { adalah sopan } \\
\text { dan } \\
\text { sesuai.Selalu } \\
\text { mendengarkan, } \\
\text { berbagi dengan, } \\
\text { dan mendukung } \\
\text { upaya orang lain }\end{array}$ & $\begin{array}{c}3 \\
\text { Baik } \\
\text { Mendengarkan, } \\
\text { berbagi, dan } \\
\text { mendukung } \\
\text { orang } \\
\text { lain.Pernyataan } \\
\text { dan tanggapan } \\
\text { adalah bahasa } \\
\text { tubuh yang } \\
\text { sopan dan } \\
\text { pantas } \\
\text { dipamerkan. }\end{array}$ & $\begin{array}{c}2 \\
\text { Cukup } \\
\text { Sebagian besar } \\
\text { pernyataan, } \\
\text { tanggapan, dan } \\
\text { bahasa tubuh } \\
\text { sangat } \\
\text { dihargai;kadang- } \\
\text { kadang memiliki } \\
\text { nada } \\
\text { negatif.Tidak } \\
\text { selalu } \\
\text { mendengarkan, } \\
\text { berbagi dengan, } \\
\text { dan mendukung } \\
\text { upaya orang } \\
\text { lain. }\end{array}$ & $\begin{array}{c}1 \\
\text { Kurang } \\
\text { Pernyataan, } \\
\text { tanggapan dan / } \\
\text { atau bahasa tubuh } \\
\text { secara konsisten } \\
\text { tidak } \\
\text { menghormati.Jarang } \\
\text { mendengarkan, } \\
\text { berbagi dengan, dan } \\
\text { mendukung upaya } \\
\text { orang lain }\end{array}$ \\
\hline $\begin{array}{l}\text { Tunjukkan } \\
\text { kemampuan } \\
\text { untuk bekerja } \\
\text { secara efektif dan } \\
\text { hormat dengan } \\
\text { tim yang } \\
\text { beragam }\end{array}$ & . & & & \\
\hline
\end{tabular}

\section{KESIMPULAN DAN SARAN}

\section{Kesimpulan}

Edutech for Children adalah pengenalan proses perancangan rekayasa pada siswa sekolah dasar dan menengah. Pelatihan ini dimaksudkan untuk memberikan kemampuan teknis siswa menggunakan perangkat lunak Autodesk inventor untuk menggambarkan purwarupa virtual tiga dimensi. Selain hal tersebut, dengan pelatihan yang diberikan siswa juga diharapkan akan mampu bekerja sama, berpikir kreatif dan memahami proses perancangan rekayasa untuk menghasilkan inovasi teknologi yang merupakan solusi yang tepat bagi permasalahan $\mathrm{d}$ lingkungannya. Siswa yang mengikuti pelatihan diberikan kesempatan untuk mendapatkan pengalaman dengan bekerja bersama anggota lain didalam kelompok dengan tujuan untuk mendapatkan solusi bersama.

\section{Saran}

Edutech for Children adalah satu bentuk kegiatan pelatihan yang dapat dilaksanakan akibat adanya kerjasama yang baik dengan pihak sekolah, diharapkan untuk kedepannya dapat juga melibatkan pemerintah daerah untuk mengadakan kegiatan serupa untuk memasyarakatkan teknologi pada anak usia sekolah, dengan demikian akan mempersiapkan generasi yang 
mampu bersaing secara global. Dengan adanya mahasiswa sebagai fasilisator, dapat mendorong siswa untuk lebih antusias didalam memahami materi proses perancangan rekayasa, oleh sebab itu pola seperti ini juga dapat diterapkan di sekolah untuk mata pelajaran tertentu yang mengajarkan ilmu teknik.

\section{UCAPAN TERIMA KASIH}

Terima kasih kepada ketua jurusan dan rekan di jurusan teknik elektro UMRAH serta Sekolah SDN 04 Teluk Sebong yang telah memberikan kesempatan melakukan Edutech for Childrendalam rangka mempersiapkan inovator dan technopreneuer di masa depan.

\section{DAFTAR PUSTAKA}

[1] Windl, S. A., dar, M. A., Lingle, J. A., Moore, R., dan Asilkalkan, A., (2019). Exploring student understanding of the engineering design process using distractor analysis, International Journal of STEM Education

[2] Lucas, B., dan Hanson, J., (2016). Thinking Like an Engineer: Using Engineering Habits of Mind and Signature to Redesign Engineering Education, iJEP, 6(2) [3] Kastner, S., dan Knight, R. T., (2017). Bringing Kids into the Scientific Review Process, Neuron, 93(1) : 12-14.

[3] Kastner, S., dan Knight, R. T., (2017). Bringing Kids into the Scientific Review Process, Neuron, 93(1) : 12-14.

[4] Collins, P., K., (2015). Building a Local Design and Entrepreneurship Ecosystem,Procedia Technology, Vol., pp 258-262

[5] Pereira, J., C., dan Russo, R. F.S.M., (2018). Design Thinking Integrated in Agile Software Development: A
Systematic Literature Review, Procedia Computer Science, Vol. 138, pp 775782

[6] Blindheim, J., Wulvik, A., dan Steinert, M., (2016) Using Secondary Video Material for User Observation in The Needfinding Process for New Product Development and Design, International Design Conference - Design 2016

[7] Nusyirwan, D., (2018). Design Thinking sebagai Bridge of Innovation Perguruan Tinggi dan Industri di Jurusan Teknik Elektro Universitas Maritim Raja Ali Haji (UMRAH), Jurnal Sustainable, 7(2) : 86-94

[8] Yim, H., dan Lee, K., (2015). Preliminary Modular Design for electric Personal Mobility with Design-Engineering Collaboration, World Electric Vehicle Journal, WEVJ7-0426

[9] Tovey, M., Porter, S., dan Newman, R., (2003). Sketching, concept development and automotive design, Design Studies, 24(2) : 135-153

[10] Łukaszewicz, K., (2017).Use of CAD Software in the Process of Virtual Prototyping of Machinery, 7th International Conference on Engineering, Project, and Production Management, Procedia Engineering $182,425-433$

[11] Wang, Z., (2011). Interactive virtual prototyping of a mechanical system considering the environment effect . Part 2: Simulation quality, Comptes Rendus Mécanique, 339(9) : 605-615

[12] Sekolah Kita SDN 04 Teluk Sebong [Daring], Tersedia pada : https://referensi.data.kemdikbud.go.id/t abs.php?npsn=11001923 [ Diakses : 10 November 2019 ].

[13] Tahapan pada Proses Desain Rekayasa Stanford Design School dengan pendekatan Design Thinking [Daring], Tersedia pada : https://www.enterpriseirregulars.com [ Diakses : 10 November 2019 ]. 